\title{
URGENSI STIMULASI KEMAMPUAN MOTORIK KASAR PADA ANAK USIA DINI
}

\author{
Bonita Mahmud \\ mahmud.bonita@gmail.com \\ Program Studi Pendidikan Islam Anak Usia Dini \\ Institut Agama Islam Negeri (IAIN) Bone
}

\begin{abstract}
Age 0 - 8 years is the golden age. In this age the child's brain is like a sponge, which is all things that are seen, heard, and felt by children absorbed well by the child. Therefore at this time the child must get the right stimulation in every aspect of his development. One aspect that must be stimulated is gross motoric. This aspect relates to the child's ability to move the large parts of his body, such as the hands and feet. Some activities that can be given to children related to gross motoric skills are jumping, walking, running, and throwing a ball. The disruption of the development of gross motoric aspects in children can affect the development to other aspects. Therefore, the gross motoric aspect must be the one of teachers and parents' concerns as a result the child's development tasks can be achieved according to his age.
\end{abstract}

Keywords: stimulation, gross motoric, early childhood

\section{PENDAHULUAN}

Usia dini (0-8 tahun) merupakan usia yang sangat menentukan bagi pertumbuhan dan perkembangan manusia selanjutnya. Hal ini disebabkan karena perkembangan otak pada masa ini mengalami percepatan hingga $80 \%$ dari keseluruhan otak orang dewasa. Itulah sebabnya masa ini biasa juga disebut sebagai golden age. Adapun definisi anak usia dini dijelaskan dalam Undang-undang Republik Indonesia Nomor 20 Tahun 2003 tentang Sistem Pendidikan Nasional Bab I Pasal 1 Butir 14 dinyatakan bahwa: 
"Pendidikan anak usia dini adalah suatu upaya pembinaan yang ditujukan kepada anak sejak lahir sampai dengan usia enam tahun yang dilakukan melalui pemberian rangsangan pendidikan untuk membantu pertumbuhan dan perkembangan jasmani dan rohani agar anak memiliki kesiapan dalam memasuki pendidikan lebih lanjut."

Masa usia dini merupakan kesempatan emas bagi para orang tua untuk mengoptimalkan berbagai potensi yang dimiliki oleh anaknya. Pemberian stimulasi yang baik akan membantu anak untuk mengembangkan seluruh aspek perkembangannya. Hal inilah yang menjadi alasan tentang pentingnya mendeteksi sejak usia dini pada setiap kemampuan yang muncul pada diri anak. Hal ini sejalan dengan yang ada dalam Undangundang Republik Indonesia Nomor 20 Tahun 2003 tentang Sistem Pendidikan Nasional Bab IV Pasal 19 Butir 1 dinyatakan bahwa:

"Proses pembelajaran pada satuan pendidikan diselenggarakan secara interaktif, inspiratif, menyenangkan, menantang, memotivasi peserta didik untuk berpartisipasi aktif, serta memberikan ruang yang cukup bagi prakarsa, kreativitas, dan kemandirian sesuai dengan bakat, minat, dan perkembangan fisik serta psikologis peserta didik."

Pemberian stimulasi pada anak usia dini sangat penting bagi perkembangan anak selanjutnya. Hal ini disebabkan karena masa usia dini merupakan masa peka bagi anak dalam menerima rangsangan atau stimulus. Salah satu aspek perkembangan yang harus distimulasi pada anak usia dini adalah kemampuan motorik kasar. Kemampuan ini berhubungan dengan kecakapan anak dalam menggerakkan bagian tubuhnya yang besar, seperti tangan dan kaki. Berjalan, berlari, melompat, keseimbangan tubuh, dan koordinasi gerak adalah bentuk-bentuk perkembangan motorik kasar pada anak.

Perkembangan motorik kasar pada anak adalah salah satu aspek penting yang harus diperhatikan oleh guru dan orang tua. Anak yang memiliki kemampuan motorik kasar yang baik akan lebih luwes dalam bergaul dengan teman-temannya. Hal ini tentu saja akan berpengaruh pada kepercayaan diri anak saat bersosialisasi dengan teman-temannya. Hal ini ditegaskan oleh pernyataan dari Alzena Masykouri bahwa anak yang memiliki kemampuan motorik kasar yang baik akan membuatnya menjadi lebih gesit dan sigap. Gerakannya menjadi lebih terkoordinasi dan membuat anak tampil lebih percaya diri. Hal ini akan membuat anak mampu bersikap luwes dalam pergaulannya. Selain itu, koordinasi gerakan yang baik akan membantunya menampilkan sikap perencanaan yang baik. Hal ini akan membuat anak semakin terampil dalam menyelesaikan persoalan sehari-hari yang dihadapinya (Anonim a). 
Salah satu contoh anak yang pernah mengalami masalah yang berhubungan dengan kemampuan motorik kasarnya adalah Arvi. Sejak usia 5 tahun, Arvi adalah anak yang tergolong aktif. Arvi senang bermain kejar-kejaran, bermain sepeda, layang-layang, dan bulu tangkis. Namun, ketika Arvi mengalami demam tinggi, orang tuanya melarangnya untuk bermain di luar rumah. Orang tuanya menyedikan playstation agar Arvi tidak lagi bermain di luar rumah dan hal ini berlangsung selama enam bulan. Hal ini pun berdampak pada perkembangan motorik kasar Arvi. Arvi mengalami kesulitan dalam hal menjaga keseimbangan tubuhnya pada saat bermain dengan teman-temannya (Anonim a).

Berdasarkan contoh kasus yang dialami Arvi menunjukkan bahwa masih ada orang tua yang belum mengetahui pentingnya menstimulasi kemampuan motorik kasar pada anak. Sebagian besar orang tua lebih memilih menyediakan fasilitas bermain di rumah bagi anaknya. Sebagai contoh, orang tua memberikan fasilitas gadget yang di dalamnya terdapat berbagai aplikasi game online yang dapat dimainkan oleh anak-anaknya. Faktor keamanan menjadi salah satu alasan sebagian besar orang tua melarang anaknya melakukan aktivitas yang bisa melatih kemampuan motorik kasarnya di luar rumah.

Hal serupa juga terjadi di beberapa sekolah, khususnya di kota-kota besar. Sebagian besar sekolah lebih fokus meningkatkan kemampuan kognitif anak, khususnya kemampuan calistung. Tidak sedikit sekolah yang memberikan les calistung ke peserta didiknya. Sebagian besar guru mengakui bahwa pemberian les calistung tersebut dilakukan karena permintaan dari orang tua anak. Orang tuanya ingin memasukkan anaknya ke sekolah favorit yang mensyaratkan calon peserta didiknya harus memiliki kemampuan calistung. Kondisi inilah yang menyebabkan sebagian besar orang tua dan tenaga pendidik lebih banyak memberikan stimulasi pada aspek kognitifnya dibanding aspek perkembangan yang lain, khususnya motorik kasar.

\section{A. Definisi Kemampuan Motorik Kasar}

George H. Sage (1984) mengemukakan bahwa kemampuan motorik adalah kapasitas individu yang berhubungan dengan kinerja dalam melakukan berbagai keterampilan yang didapatkannya sejak masa kanak-kanak. Kemampuan ini menjadi pondasi untuk melakukan berbagai tugas. Kemampuan dalam melakukan sesuatu dipelajari melalui berbagai praktek dan bergantung pada kemampuan yang mendasarinya, seperti keseimbangan (Sage, 1984:274). 
Fikriyati (2013:21-22) mengemukakan bahwa kemampuan motorik sangat erat kaitannya dengan perkembangan pengendalian gerakan tubuh melalui kegiatan yang terkoordinir antara susunan saraf, otot, otak, dan spinal cord. Adapun definisi motorik kasar adalah gerakan tubuh yang menggunakan otot-otot besar atau sebagian besar atau seluruh anggota tubuh yang dipengaruhi oleh kematangan anak itu sendiri. Ada beberapa contoh aktivitas yang melibatkan kemampuan motorik kasar, yaitu duduk, menendang, berlari, melompat, berjalan, naik turun tangga, dan sebagainya. Anak yang dapat menguasai gerakan motoriknya, maka kondisinya tubuhnya akan semakin sehat karena selalu bergerak. Hal ini tentunya akan berpengaruh pada kemandirian dan rasa percaya diri anak. Anak lebih mudah dalam bersosialisasi karena mampu mengimbangi gerakan dan aktivitas yang dilakukan bersama teman-teman sebayanya.

Gallahue (1989) juga mengemukakan bahwa kemampuan motorik kasar sangat berhubungan dengan kerja otot-otot besar pada tubuh manusia. Kemampuan ini biasanya digunakan oleh anak untuk melakukan aktivitas olahraga. Kemampuan ini berhubungan dengan kecakapan anak dalam melakukan berbagai gerakan. Gallahue (1989, 45-46) membagi kemampuan motorik dalam tiga kategori, yaitu:

1. Kemampuan lokomotor adalah kemampuan yang digunakan untuk memindahkan tubuh dari suatu tempat ke tempat yang lain, seperti berjalan, berlari, melompat, dan meluncur.

2. Kemampuan non-lokomotor adalah kemampuan yang digunakan tanpa memindahkan tubuh atau gerak di tempat. Contoh gerakan kemampuan nonlokomotor adalah menekuk dan meregang, mendorong dan menarik, jalan di tempat, loncat di tempat, berdiri dengan satu kaki, dan mengayuhkan kaki secara bergantian.

3. Kemampuan manipulatif adalah kemampuan yang dikembangkan saat anak sedang menguasai berbagai macam objek dan kemampuan ini lebih banyak melibatkan tangan dan kaki. Contoh kemampuan manipulatif adalah gerakan melempar, memukul, menendang, menangkap obyek, memutar tali, dan memantulkan atau menggiring bola.

Perkembangan kemampuan ini pada setiap usia perkembangan anak tentunya berbeda-beda. Hal ini sesuai dengan yang dikemukakan oleh Gallahue (1989, 46-53) bahwa perkembangan gerak yang melibatkan kemampuan motorik kasar pada anak terdiri dari beberapa fase, yaitu: 


\section{Reflexive Movement Phase}

Fase ini dimulai saat bayi pertama kali membuat gerakan refleks di dalam kandungan sampai usia 1 tahun. Pada fase ini bayi membuat gerakan refleks untuk mengetahui keadaan di sekitarnya. Biasanya bayi akan bereaksi pada stimulus yang berupa sentuhan, cahaya, atau pun suara-suara.

\section{Rudimentary Movement Phase}

Fase ini dimulai saat anak berusia $1-2$ tahun. Kemampuan anak di usia ini berbedabeda tergantung dari stimulus yang didapatkannya dari lingkungannya. Anak juga mulai belajar untuk menjaga keseimbangannya, misalnya anak mulai belajar mengontrol gerakan kepala, leher, dan batang otot serta melakukan gerakan lokomotor (merayap, merangkak, dan berjalan).

\section{Fundamental Movement Phase}

Fase ini dimulai sejak anak berusia $2-7$ tahun. Fase ini merupakan kelanjutan dari fase perkembangan gerak sebelumnya. Pada fase ini anak sudah mulai belajar mengeksplor tubuhnya dalam melakukan gerakan. Anak juga sudah banyak melakukan gerakan lokomotor, non-lokomotor, dan manipulatif. Contoh gerak lokomotor yang banyak dilakukan oleh anak adalah berlari dan melompat, gerak non-lokomotor seperti berdiri dengan satu kaki, serta gerak manipulatif seperti melempar dan menangkap. Perkembangan gerak anak pada fase ini sangat dipengaruhi oleh faktor kesempatan untuk mempraktekkan secara langsung, dorongan, dan arahan saat melakukan permainan-permainan yang bisa mengembangkan kemampuan geraknya.

\section{Specialized Movement Phase}

Fase ini dimulai sejak anak berusia 7 tahun dan berlanjut hingga anak dewasa. Fase ini merupakan kelanjutan dari fase perkembangan sebelumnya. Pada fese ini anak sudah mulai bisa melakukan gerakan kombinasi antara lokomotor, non-lokomotor, dan manipulatif, khususnya pada kegiatan olahraga. Anak juga mulai belajar untuk menyempurnakan gerakannya tanpa bantuan orang dewasa di sekitarnya. Namun, pemberian stimulus dan kesempatan kepada anak untuk melakukan praktek harus tetap diberikan.

Artikel ini akan berfokus pada fundamental movement phase yang berlangsung sejak anak berusia 2 - 7 tahun. Fase ini dikembangkan pada masa anak sebelum sekolah dan pada masa sekolah awal. Pada fase ini kemampuan motorik kasar anak sebaiknya banyak 
distimulasi. Hal ini disebabkan karena kemampuan yang didapatkannya pada fase fundamental akan menjadi bekal awal untuk mendapatkan keterampilan gerak yang efisien dan bersifat umum. Bekal awal inilah yang selanjutnya akan dipergunakan sebagai dasar untuk perkembangan motorik yang lebih khusus. Pada sebuah penelitian menunjukkan bahwa satu dari lima anak usia taman kanak-kanak mengalami keterlambatan perkembangan kemampuan motorik dasar (fundamental dasar skill). Hal ini menunjukkan bahwa latihan sangat dibutuhkan sebagai salah satu bentuk stimulasi kemampuan motorik dasar anak. Anak yang tidak mendapatkan stimulasi akan tetap berada pada tingkat dasar (fase rudimentary) (Temple dalam Kiram, 1992:42).

Dari berbagai teori yang telah dikemukakan, maka dapat disimpulkan bahwa kemampuan motorik kasar adalah kecakapan dalam melakukan berbagai gerakan fisik yang membutuhkan keseimbangan, baik gerak sebagian maupun seluruh anggota tubuh yang terdiri dari gerak lokomotorik, non-lokomotorik, dan manipulatif.

\section{B. Stimulasi untuk Meningkatkan Kemampuan Motorik Kasar Anak}

Kemampuan motorik kasar adalah salah satu aspek perkembangan anak yang harus mendapatkan stimulasi. Stimulasi adalah perangsangan yang diperoleh anak yang bersumber dari lingkungan di luar individu. Stimulasi yang diberikan kepada anak bisa juga berfungsi sebagai penguat atau reinforcement. Stimulasi adalah salah satu hal penting dalam proses tumbuh kembang anak. Tumbuh kembang anak akan lebih cepat jika mendapatkan stimulasi yang terarah dan teratur (Soetjiningsih, 2012:105). Hal lain yang harus diperhatikan saat memberikan stimulasi adalah orang tua atau pun guru harus memberikan stimulasi sesuai dengan kebutuhan dan usia perkembangan anak.

Gesel dan McGrow pernah melakukan sebuah eksperimen dimana anak dibagi menjadi dua kelompok. Salah satu kelompok diberikan stimulasi untuk meningkatkan kemampuan motorik kasarnya dan kelompok yang lain tidak diberikan stimulasi. Hasil penelitiannya menunjukkan bahwa anak yang mendapatkan stimulasi motorik kasar memiliki performance motorik kasar yang lebih baik dibanding anak yang tidak mendapatkan stimulasi. Hasil penelitian ini juga menunjukkan bahwa anak harus diberikan kesempatan untuk melakukan praktek langsung dan diberikan stimulasi untuk meningkatkan kemampuan motorik kasarnya (Gallahue, 1989:73).

Berdasarkan hasil penelitian tersebut, maka dapat disimpulkan bahwa lingkungan memiliki peran yang penting dalam perkembangan kemampuan motorik kasar anak. Hal ini 
sesuai dengan yang dikemukakan oleh Upton bahwa anak harus diberikan kesempatan untuk mengeksplor hal-hal yang ada di lingkungannya. Orang tua maupun guru harus memberikan kesempatan kepada anak untuk melatih kemampuan motorik kasarnya. Kesempatan untuk berlatih bagi tiap anak sangat penting dalam mempengaruhi umur aktual ketika tonggaktonggak perkembangannya tercapai (Upton, 2012:62-63).

Salah satu cara untuk menstimulasi perkembangan motorik kasar anak adalah melalui aktivitas bermain di luar ruangan. Sekolah bisa menyediakan alat permainan yang bisa melatih kemampuan motorik kasar pada anak. Bagi sekolah yang tidak memiliki area bermain yang cukup luas, maka guru bisa memanfaatkan ruangan yang ada di sekolah. Guru bisa menciptakan permainan sederhana yang dapat melatih kemampuan motorik kasar anak. Hal ini juga ditegaskan oleh Fikriyati bahwa pemaksimalan ruangan bisa dijadikan strategi untuk menyediakan ruang gerak yang bebas bagi anak untuk berlari, melompat, dan menggerakkan seluruh tubuhnya dengan cara-cara yang tidak terbatas Gallahue $(1989,28)$.

Pada umumnya ada tiga cara yang dapat dilakukan anak dalam mengembangkan kemampuan motorik kasarnya Fikriyati (2013:32-33), yaitu:

1. Coba-coba, anak melakukannya sendiri dengan coba-coba tanpa bantuan orang lain. Anak melakukannya secara acak sehingga bisa menyebabkan keterampilan yang diperoleh anak di bawah kemampuan si anak.

2. Meniru, anak mengamati suatu model dari orang-orang yang berada di sekitarnya kemudian menirunya. Kelemahan dari cara ini adalah anak bisa saja meniru kelemahan atau keterbatasan dari model.

3. Pelatihan, anak belajar dengan bimbingan guru, orang tua, atau pengasuh sehingga dapat meniru dengan tepat. Kehadiran pembimbing juga dapat menggunakan alat bantu berupa benda-benda yang ada di sekitar atau alat permainan edukatif.

Ada juga beberapa kegiatan yang dapat dilakukan oleh orang tua dan guru PAUD untuk menstimulasi kemampuan motorik kasar anak usia dini menurut Wiyani (2013:65-66), yaitu:

1. Berjalan dengan berbagai gerakan.

2. Berjalan naik turun tangga.

3. Berjalan dengan papan titian maju, mundur, ke samping sambil membawa benda.

4. Meminta anak berdiri sambil memegang bola kemudian bola dilemparkan ke atas dan anak berusaha menangkap kembali bola tersebut. 
5. Membuat dua garis yang lebarnya $50 \mathrm{~cm}$ ibarat sebuah parit, diharapkan anak melintasi garis tersebut dengan cara melompatinya.

Berdasarkan pemaparan para ahli di atas, maka dapat disimpulkan bahwa untuk meningkatkan kemampuan motorik kasar anak maka orang tua dan guru harus memberikan stimulasi kepada anak. Stimulasi yang diberikan harus disesuaikan dengan usia perkembangan anak. Stimulasi motorik kasar ini bisa diberikan melalui aktivitas bermain. Selain itu, orang tua dan guru juga dapat memberikan program stimulasi melalui rangkaian proses latihan yang terarah dan teratur.

\section{Tahapan Pembelajaran Gerak Motorik Pada Anak Usia Dini}

Saat anak mempelajari suatu gerakan dasar (misalnya melompat, berjalan, atau berlari) tentunya ada tahapan-tahapan yang harus dilewati anak agar biasa menguasai gerakan tersebut. Fitts dan Posner mengemukakan beberapa tahapan belajar motorik (Lutan, 1988:305-307), yaitu:

\section{Tahap Kognitif}

Pada tahap ini anak membutuhkan informasi tentang cara melakukan suatu gerakan.

Tugas guru atau pelatihlah yang sangat berperan dalam tahapan ini. Pada tahapan ini anak sering melakukan kesalahan, gerakannya masih kaku, dan kurang terkoordinasi.

2. Tahap Asosiatif

Pada tahapan ini anak mulai bisa menyesuaikan diri dengan gerakan yang telah dipelajarinya. Gerakan yang dihasilkan oleh anak juga sudah mulai konsisten dan kesalahan dalam melakukan gerakan sudah mulai berkurang.

3. Tahap Otomatis

Setelah melewati proses latihan, anak memasuki tahap otomatis. Gerakan yang dilakukan oleh anak sudah tidak terganggu oleh kegiatan lainnya yang terjadi secara simultan. Gerakan yang dilakukan oleh anak terjadi secara otomatis dan tingkat kesalahan dalam melakukan gerakan semakin berkurang.

Berdasarkan pemaparan di atas tentang tahapan pembelajaran gerak motorik, maka dapat disimpulkan bahwa ada tiga tahapan yang akan dilewati oleh anak dalam mempelajari gerakan motorik, yaitu tahapan kognitif, asosiatif, dan otomatis.

\section{Urgensi Stimulasi Kemampuan Motorik Kasar Bagi Anak Usia Dini}

Kemampuan motorik kasar anak bisa ditingkatkan melalui sebuah proses latihan. Guru bisa membuat berbagai program stimulasi untuk meningkatkan kemampuan tersebut. 
Papalia, Olds, dan Feldman mengemukakan bahwa perbedaan kemampuan motorik antara anak yang satu dengan yang lain disebabkan oleh faktor kesempatan dan stimulus yang didapatan oleh anak. Anak yang mendapatkan kesempatan untuk berlatih dan stimulus yang tepat tentunya akan memiliki ketangkasan yang lebih baik dibanding dengan anak yang tidak mendapatkan kedua hal tersebut (Papalia et al., 2009:327). Hal ini sejalan dengan teori behaviorisme yang dikemukakan oleh Jhon B. Watson. Tokoh behaviorisme ini mengemukakan teori stimulus-respons dimana stimulus yang diberikan kepada seseorang berkaitan langsung dengan respon tertentu. Hal inilah yang menjadi asumsi dasar dalam mempelajari gerak motorik dasar. Saat anak mempelajari suatu gerakan tertentu, maka pada saat itu terjadi pembentukan koneksi stimulus-respons. Proses koneksi tersebut dipahami sebagai pembentukan pertautan (bond) antara stimulus-respons yang tidak terjadi secara otomatis. Koneksi yang terjadi merupakan hasil dari proses latihan atau belajar individu. Stimulus yang berkaitan dengan respons yang melibatkan gerakan tubuh inilah yang disebut sebagai motor bond (Lutan, 1988:122-124).

Salah satu aspek yang harus dikembangkan pada perkembangan motorik kasar pada anak adalah kemampuan melompat. Anak harus memiliki perencanaan gerak, kemampuan koordinasi motorik, dan keseimbangan yang baik untuk melakukan aktivitas melompat ini. Pada perencanaan gerak dibutuhkan kemampuan otak untuk membuat perencanaan dan dilaksanakan oleh motorik dalam bentuk gerak yang terkoordinasi. Kemampuan perencanaan gerak akan memacu otak untuk melatih konsentrasi. Hal yang berbeda akan terjadi bagi anak yang memiliki perencanaan gerak yang tidak berkembang dengan baik. Anak akan bermasalah dalam keseimbangannya. Anak akan lebih mudah lelah dalam beraktivitas fisik dan sulit berkonsentrasi. Anak juga cenderung menghindari tugas-tugas yang melibatkan konsentrasi dan aktivitas yang melibatkan kemampuan mental, seperti memasang puzzle, tidak mau mendengarkan saat guru bercerita, dan sebagainya. Contoh kegiatan perencanaan gerak adalah saat anak ingin melompati sebuah tali. Anak harus sudah mempunyai rencana apakah anak akan mendarat dengan satu kaki atau dua kaki. Jika anak menggunakan satu kaki, kaki mana yang akan digunakannya (Wiyani, 2013:63-64).

Hal lain yang harus distimulasi oleh orang tua maupun guru adalah kemampuan melempar anak. Sensoris keseimbangan, rasa sendi (propriosepsi), dan visual adalah faktorfaktor yang berperan dalam kemampuan melempar anak. Peran yang paling utama adalah rasa sendi, yaitu kemampuan sendi merasakan suatu gerakan atau aktivitas. Sebagai contoh, yaitu saat anak melempar bola, seberapa kuat dan lemahnya lemparannya, agar bola bisa 
masuk ke dalam keranjang. Anak akan mengalami masalah dalam aktivitas yang melibatkan gerak ekstremitas atas (bahu, lengan bawah, tangan, dan jari-jari tangan), jika kemampuan melempar tidak terstimulasi dengan baik. Hal ini juga akan mempengaruhi kemampuan motorik halus pada anak. Tulisan anak akan terlalu menekan sehingga ada beberapa anak yang tulisannya sampai menembus kertas, terlalu kurang menekan (tulisannya tipis), atau antar hurufnya berjarak. Aktivitas motorik halus lain yang ikut terganggu apabila kemampuan ini tidak terstimulasi dengan baik adalah anak akan mengalami kesulitan dalam memakai kancing baju, mengikat tali sepatu, makan sendiri, menyisir, dan sebagainya (Wiyani, 2013:64).

Perkembangan motorik kasar adalah salah satu aspek perkembangan yang sangat penting bagi anak. Aspek ini juga berkaitan erat dengan sistem saraf yang ada di otak manusia. Otak merupakan pusat dari semua sistem yang ada di dalam tubuh manusia, begitu pun ketika individu tersebut akan melakukan sebuah aktivitas atau gerakan. Otak Kecil atau cerebellum merupakan bagian dari otak yang berfungsi mengontrol banyak fungsi otomatis otak, diantaranya: mengatur sikap atau posisi tubuh, mengontrol keseimbangan, koordinasi otot dan gerakan tubuh. Bagian ini terletak di bagian belakang kepala, dekat dengan ujung leher bagian atas (Anonim b).

Otak manusia hanya satu yang terdiri dari belahan otak kanan dan belahan otak kiri. Kedua belahan otak tersebut harus selalu dalam keseimbangan, tetapi kenyataannya tidak begitu adanya. Salah satu cara untuk membantu menyeimbangkan belahan otak kiri dan belahan otak kanan adalah melalui sebuah aktivitas bermain. Permainan berlari yang menyenangkan akan membantu dalam menyeimbangkan belahan otak kiri dan belahan otak kanan bagi anak usia dini. Aktivitas berjalan dan berlari adalah aktivitas alami yang menggunakan pola bersilang dan sangat berguna dalam menyeimbangkan belahan otak kanan dan otak kiri (Wiyani, 2013:60).

Berdasarkan pemaparan diatas, maka dapat dikatakan bahwa kemampuan motorik kasar ini sangat penting terhadap kinerja belahan otak pada anak. Hal ini tentunya akan berpengaruh pada kondisi perkembangan anak. Hurlock mengemukakan bahwa ada beberapa pengaruh perkembangan motorik terhadap konstelasi perkembangan individu Fikriyati (2013:26-27), yaitu:

1. Melalui keterampilan motorik, anak dapat menghibur dirinya dan memperoleh perasaan senang. Contohnya, anak akan merasa senang dengan memiliki keterampilan dalam melempar dan menangkap bola. 
2. Melalui keterampilan motorik, anak mampu bergerak dari satu tempat ke tempat yang lain dan dapat berbuat sendiri untuk dirinya. Hal ini akan menunjang kemandirian dan rasa percaya diri anak.

3. Melalui perkembangan motorik, anak akan menjadi lebih mudah dalam menyesuaikan diri dengan lingkungan sekolahnya. Hal ini disebabkan karena usia kelas-kelas awal sekolah dasar anak sudah dilatih kemampuan baris-berbaris.

4. Anak yang memiliki perkembangan motorik yang baik akan lebih mudah bersosialisasi dengan teman-teman sebayanya.

Pentingnya keterampilan gerak bagi anak usia dini juga dikemukakan dalam teori Piaget tentang hierarki perkembangan kognitif anak. Anak memerlukan skemata agar kemampuan kognitifnya berkembang secara normal. Perkembangan secara normal akan terjadi ketika anak mendapat kesempatan untuk secara aktif mengeksplorasi lingkungannya. Selain itu, keterampilan gerak pada anak usia dini tidak hanya bermanfaat bagi pertumbuhan fisik anak tetapi juga perkembangan mentalnya. Pengalaman gerak bagi anak bermanfaat sebagai basis perkembangan selanjutnya atau Piaget menyebutnya dengan istilah skemata (Lutan, 1988:367-368).

Dari pemaparan beberapa ahli tentang manfaat kemampuan motorik kasar bagi anak, maka dapat disimpulkan bahwa kemampuan motorik dasar ini penting bagi perkembangan anak. Anak yang memiliki kemampuan motorik kasar yang baik akan memiliki perkembangan mental yang baik juga. Hal ini disebabkan karena anak mampu menyesuaikan diri dengan lingkungan sekitarnya. Hal ini tentu saja akan meningkatkan rasa percaya diri anak. Selain itu, anak yang terlatih kemampuan motorik kasarnya akan berpengaruh positif pada kemampuan kognitifnya. Melatih kemampuan motorik kasar anak sama saja dengan membantu menyeimbangkan kinerja belahan otak kanan dan belahan otak kiri pada anak.

\section{PENUTUP}

Motorik kasar adalah salah satu aspek perkembangan yang harus diperhatikan dalam proses tumbuh kembang anak. Kemampuan motorik kasar adalah kecakapan dalam melakukan berbagai gerakan fisik yang membutuhkan keseimbangan, baik gerak sebagian maupun seluruh anggota tubuh yang terdiri dari gerak lokomotorik, non-lokomotorik, dan manipulatif. 
Salah satu bentuk perhatiannya adalah dengan memberikan program stimulasi yang tepat sesuai dengan kebutuhan dan usia perkembangan anak. Stimulasi adalah perangsangan yang diperoleh anak yang bersumber dari lingkungan di luar individu. Anak yang memiliki kemampuan motorik kasar yang baik akan memudahkannya untuk bisa cepat beradaptasi dengan lingkungannya. Selain itu, kepercayaan dirinya juga akan meningkat sehingga anak bisa lebih mengeksplor lingkungannya. Hal ini juga akan berdampak pada perkembangan mental anak yang ikut terstimulasi dengan baik. Oleh karena itu, stimulasi yang baik pada kemampuan motorik kasar anak akan mempengaruhi aspek perkembangan yang lainnya.

\section{DAFTAR PUSTAKA}

Anonim a. Pentingnya Olahraga Sebagai Stimulasi Motorik Anak (http://www.ibudanbalita.com,) diakses pada tanggal 20 Juli 2018).

Anonim b. Anatomi \& Fungsi Otak Manusia (http://www.aktivasiotak.com/fungsiotak.htm, diakses pada tanggal 20 Juli 2018.

Fikriyati, Mirroh. 2013. Perkembangan Anak Usia Emas (Golden Age). Yogyakarta: Laras Media Prima.

Gallahue, David L. 1989. Understanding Motor Development Infants, Children, Adolescents Second Edition. USA: Benchmark Press.

Lutan, Rusli. 1989. Belajar Keterampilan Motorik, Pengantar Teori, dan Metode. Jakarta: Departemen Pendidikan dan Kebudayaan.

Kiram, Phil Yanuar. 1992. Belajar Motorik. Jakarta: Departemen Pendidikan dan Kebudayaan Direktorat Jenderal Pendidikan Tinggi Proyek Pembinaan Tenaga Kependidikan.

Papalia, Olds, dan Feldman. 2009. Perkembangan Manusia Edisi Kesepuluh, Terjemahan oleh Brian Marswendy. Jakarta: Penerbit salemba Humanika.

Sage, George. 1984. Motor Learning and Control A Neuropsychological Approach. USA: Wm. C. Brown Publishers.

Soetjiningsih. 2012. Tumbuh Kembang Anak. Jakarta: Penerbit Buku Kedokteran EGC.

Undang-undang Republik Indonesia Nomor 20 Tahun 2003 tentang Sistem Pendidikan Nasional.

Upton, Penney. 2012. Psikologi Perkembangan,Terjemahan oleh Noermalasari Fajar Widuri. Jakarta: Erlangga.

Wiyani, Novan Ardy. 2013. Bina Karakter Anak Usia Dini. Jogjakarta: Ar Ruzz Media. 